\title{
Media dan monopoli dagang Percetakan dan penerbitan di Indonesia pada masa VOC
}

\author{
KASIJANTO
}

\begin{abstract}
ABSTR ACT
This article addresses the research on media history in Indonesia. The VOC (Vereenigde Oost-Indische Compagnie) period of the seventeenth/eighteenth century, also known as the early modern period, is regarded as a starting point in this study. It was during this time that printing machines were imported from Europe by the VOC authorities. The availability of paper and printing ink also made it possible for the production of printed matter such as forms, books, and other material. The first known printed media was the Bataviasche Nouvelles, which served as a kind of newspaper. This period saw three types of publishing houses: (1) urban publishing; (2) publishing houses working under contract; and (3) royal publishing houses. Basically however, all these different publishing activities were aimed at supporting the existence of the VOC. Publishing companies were generally engaged in providing service to the Church and meeting the VOC's administrative requirements. Communication media, based on enhancing freedom of opinion and disseminating information, would pose a problem as it would come face to face with VOC's power monopoly.
\end{abstract}

KEYWORDS

Sejarah media, VOC, percetakan, surat kabar, Bataviasche Nouvelles.

Risalah ringkas ini membahas beberapa aspek perkembangan usaha percetakan dan penerbitan pada masa VOC (Vereenigde Oost-Indische Compagnie) di Hindia Timur - sebutan untuk Indonesia pada waktu itu. ${ }^{1}$ Tema ini dipandang penting untuk dikaji dengan beberapa pertimbangan. Pertama, dilihat dari segi kurun waktu, masalah yang dipelajari berada dalam masa modern awal yang ditandai oleh persentuhan masyarakat Indonesia dengan kebudayaan Eropa. Persentuhan budaya itu diasumsikan berdampak terhadap berbagai aspek kehidupan masyarakat. Kedua, penerbitan dengan teknologi cetak tergolong unsur budaya baru pada waktu itu sehingga patut

$1 \quad$ Sebutan lain yang juga lazim digunakan ialah Kepulauan Nusantara. Dalam tulisan ini, berbagai sebutan tersebut digunakan secara berselang-seling sebagai ragam nama, tanpa bermaksud mengacaukannya secara anakronistik.

KASIJANTO adalah pengajar pada Departemen Sejarah, Fakultas Ilmu Pengetahuan Budaya, Universitas Indonesia; mempunyai minat pada sejarah sosial-budaya dan kajian Asia Tenggara. E-mail: kasijanto@ui.edu. 
ditilik apakah terjadi perubahan tertentu yang diakibatkan oleh unsur itu. Akhirnya, ketiga, dipandang perlu untuk membuka aspek yang relatif jarang dipelajari dalam kurun abad ketujuh belas dan delapan belas ini, yakni tentang media komunikasi modern sehingga penelitian singkat ini dapat pula dilihat sebagai upaya kecil menuju penulisan sejarah media.

Hakikatnya, percetakan, dan penerbitan merupakan dua hal yang berbeda tetapi berkaitan erat; yang pertama, merupakan alat (tool) atau prasarana sedangkan yang kedua, merupakan produk fisik dari pengoperasian alat tersebut. Sebagai usaha ekonomis, keduanya juga merupakan jenis usaha yang berbeda; yang pertama, merupakan bisnis sektor jasa, sedangkan yang kedua, merupakan produk barang. Dari segi keilmuan, keduanya merupakan subjek yang dapat dipelajari secara terpisah, baik dalam bidang ilmu yang sama maupun yang berbeda. Namun, dalam beberapa studi diperlihatkan pula bahwa percetakan dan penerbitan dipelajari secara komprehensif sebagai entitas yang tidak (harus) terpisah, misalnya dalam kajian tentang media budaya.

Pada dasarnya, media merupakan alat teknis yang digunakan untuk melakukan mediasi atau menyampaikan pesan; dengan kata lain media merupakan alat komunikasi. Ketika mediasi itu bersifat masal dan berlangsung dalam suatu ruang publik, media yang digunakan pun menjadi media massa. Meskipun demikian, tidak semua alat (media) yang digunakan secara masal akan dengan sendirinya menjadi media massa, kecuali apabila alat itu benar-benar diberdayakan untuk berkomunikasi dari sebuah sumber tertentu kepada sejumlah orang atau khalayak yang anonim. Secara garis besar, media terbagi menjadi dua jenis kelompok, yakni, pertama, media cetak yang meliputi surat kabar, majalah, buku, pamflet, billboard, dan alat-alat teknis lainnya yang membawa pesan kepada massa dengan cara menyentuh indera penglihatan. Jenis kedua adalah media elektronik yang terdiri dari (a) program radio dan rekaman yang menyentuh indera pendengaran dan (b) program televisi, gambar bergerak, serta rekaman video yang menyentuh indera pandang-dengar. ${ }^{2}$

Pada masa Revolusi Industri di Inggris abad kedelapan belas, jenis alat komunikasi itu bahkan mencakup jalur-jalur sungai, kereta api, jaringan pos, telegraf, mobil, kapal laut, dan kapal terbang yang kemudian lebih tepat dikategorikan sebagai sarana perhubungan dan alat angkutan (Williams 1973, Bab 1; Briggs dan Burke 2006, Bab 5). Lebih luas lagi jika pengertian tentang media tersebut diperhitungkan mulai dari bentuk-bentuk komunikasi lisan yang telah berkembang jauh sebelum ditemukan budaya tulis pada abad kedua belas dan tiga belas dan mesin cetak pada abad kelima belas. Jelas bahwa media merupakan suatu sistem yang berubah terus-menerus, yang disebabkan oleh paling kurang dua faktor, yakni pertama, kemajuan teknologi untuk menghasilkan alat yang dibutuhkan, dan kedua, tuntutan tingkat pendidikan di antara sejumlah besar orang yang akan menggunakan penyebaran informasinya. Cakupan media itu membulatkan konsep media

2 Uraian tentang taksonomi konsep media ini dapat diperiksa antara lain dalam McQuail (1987, khususnya Bab 2); Littlejohn (1996, Bab 1); Blake dan Haroldsen (2005, Bab 17). 
bukan hanya terbatas sebagai alat komunikasi tetapi juga sebagai media budaya secara lebih luas. ${ }^{3}$ Kedudukan dan fungsinya pun dikukuhkan sebagai salah satu institusi sosial yang berperan utama sebagai media kontrol dan pendidikan (McQuail 1987: 37-39; Littlejohn 1996: 330-331).

\section{Permasalahan}

Tulisan ini mengarahkan perhatian pada usaha (bisnis) percetakan dan produk cetakannya - yakni buku dan media pemberitaan - pada masa VOC dengan alasan objektif bahwa ketika itu belum ditemukan jenis media beserta teknologinya yang lain kecuali alat cetak dan media cetak. ${ }^{4}$ Dilihat dari 'hierarki' pengaruhnya kepada khalayak pembaca, media cetak, khususnya surat kabar dan majalah, merupakan media utama bersama-sama (kemudian) radio dan televisi. ${ }^{5}$ Secara singkat, dalam tulisan ini dipaparkan tipologi usaha percetakan pada masa VOC dan produk yang dihasilkannya. Selanjutnya, secara sekilas dibahas sebuah - dan satu-satunya - media pemberitaan pada masa itu, yakni Bataviasche Nouvelles, yang mungkin belum sepenuhnya menyerupai surat kabar tetapi telah menunjukkan ciri-ciri sebagai media komunikasi, seperti memuat berbagai berita, memiliki kala terbit tetap dan diedarkan kepada umum.

Permasalahan yang ditemukan ialah adanya kontradiksi antara prinsip dasar media penerbitan dengan lingkungan yang tidak mendukung keberadaannya. Pada prinsipnya, media merupakan institusi yang difungsikan untuk mengembangkan kebebasan berpendapat dan menyebarkan informasi ke segala arah, yakni kepada publik dan institusi lainnya termasuk pemerintah. Sebagai institusi, suatu media harus memiliki tenaga profesional, manajemen, dan infrastruktur. Untuk memenuhi fungsinya, media menjalin hubungan dengan sumber berita, pembaca, klien, pemilik modal, distributor, dan pihak-pihak lain. Dengan demikian, juga terlihat bahwa keberadaan media sebagai institusi sosial berkaitan dengan institusi lainnya, seperti ekonomi, politik, hukum ataupun khalayak luas (McQuail 1987: 53-55, 142-143, Bagan; Littlejohn 1996: 330-331; Croteau dan Hoynes 1997: 18-19).

Persoalan yang dihadapi media ialah apakah sinerginya dengan masyarakat dan institusi lainnya bersifat saling mendukung atau membutuhkan sehingga media itu dapat menjalankan peran komunikasi

\footnotetext{
Lihat misalnya Grossberg, Nelson, Treichler (1992); Barker (2004) yang memasukkan media sebagai bagian dari kajian budaya (cultural studies); sedangkan Briggs dan Burke (2006) memperjelas media sebagai faktor perubahan dalam sejarah sosial, khususnya di Eropa sejak akhir abad kelima belas, dan seterusnya.

4 Pemancar radio baru ditemukan Guglielmo Marconi pada 1895; demikian pula penemuan gambar bergerak dalam tempo yang sama; sedangkan stasiun televisi baru diudarakan pada tahun 1933 oleh RCA di Amerika Serikat. Sementara itu, di Eropa, mesin cetak telah ditemukan pada abad kelima belas dan mesin pembuat kertas pada tahun 1798 sehingga memungkinkan penerbitan barang cetakan (lihat Croteau dan Hoynes 1997: 9-10; Briggs dan Burke 2006, Kronologi).

Setelah surat kabar dan majalah, tingkat pengaruh media berikutnya adalah buku dan film, kemudian diikuti media lainnya seperti billboard dan barang cetakan lainnya (lihat Blake dan Haroldsen 2005: 42; bandingkan Croteau dan Hoynes 1997: 7, dan seterusnya).
} 
dan kontrolnya secara optimal. Dinamika masyarakat dan kepentingan yang berbeda-beda dari berbagai kekuatan tampaknya cenderung membuat media harus berhadapan dengan kesulitan. Dalam konteks masa VOC, media jelas memiliki kelemahan dalam kesiapan tenaga profesional; tidak jelas berapa banyak tenaga yang berkualifikasi untuk mengembangkan tugas jurnalistik, bagaimana segi bisnis harus dikelola, dan bagaimana media itu didistribusikan. Demikian pula usaha percetakan tampaknya sangat tergantung pada 'kemurahan hati' penguasa VOC, dan keberlangsungan hidupnya juga tergantung nilai utilitasnya; jika digunakan untuk tujuan yang menguntungkan penguasa maka diberi jalan, jika sebaliknya akan dilarang. Dengan demikian, usaha percetakan dan media harus berhadapan dengan kekuatan yang bersifat monopolistik dan tak ingin berbagi kesempatan ataupun kekuasaan dengan pihak lain.

\section{LANDASAN PEMIKIRAN}

Sebagai upaya penulisan sejarah media, penelitian ini bertumpu pada ancangan yang lazim dalam studi komunikasi massa. Secara garis besar, terdapat dua sudut pandang terhadap media, yakni mediacentric dan sociocentric (McQuail 1987; Littlejohn 1996). Sudut pandang pertama melihat media sebagai lembaga independen yang memiliki pengaruh kuat terhadap masyarakat, dan arah perhatiannya ditekankan pada lingkungan media yang seakan berdiri sendiri. Di sini, media dilihat sebagai salah satu bagian dari kekuatan-kekuatan masyarakat. Sementara itu, pandangan kedua melihat media tidak berdiri sendiri melainkan sebagai refleksi dari kekuatan ekonomi dan sangat tergantung pada politik yang berkembang di luarnya. Dalam pandangan ini terdapat keyakinan bahwa media menjadi sarana atau alat bagi kelompok dominan dalam mengontrol, menguasai, bahkan menyingkirkan, kelompok yang tidak dominan.

Berlandaskan pemikiran tersebut, media dan infrastrukturnya (percetakan) lebih tepat dilihat dari sudut pandang sociocentric yang pada intinya belum terjadi kondisi yang 'sehat' untuk bertumbuh dan berkembangnya usaha percetakan ataupun media. Pertama, dari segi orang Belanda sendiri, khususnya padagang VOC, muncul kesenjangan yang sangat jauh antara modernitas yang dialami di Eropa dengan negeri tempat berdagang. Kesenjangan jarak itu bukan hanya dari segi geografi tetapi juga kultural. Kedua, sifat monopolistik yang dianut oleh VOC juga jelas menjadi muskilnya asas-asas persaingan yang sehat sebagaimana layaknya dalam usaha bisnis; atau prinsip-prinsip keterbukaan dan persamaan sebagaimana dituntut oleh hakikat media. Akhirnya, ketiga, dalam masa modern awal di negeri yang tingkat keberaksaraannya diperkirakan masih rendah, jelaslah bahwa pengaruh media terhadap pembacanya sangat rendah, apalagi media itu disajikan dalam bahasa asing. Alhasil, usaha percetakan ataupun penerbitan media pada masa itu tak lebih hanya menopang, atau dimanfaatkan, kalangan terbatas, yakni kekuasaan pedagang. 


\section{USAHA PERCETAKAN}

Sepanjang diketahui, cetakan dan teknologi pencetakan telah dikenal di negeri Cina dan Jepang paling tidak sejak abad kedelapan. Terbuat dari potongan kayu, bentuknya sederhana - biasanya balok segi panjang - yang diukir dengan tulisan atau huruf-gambar (ideogram) pada salah satu permukaannya; mirip alat stempel yang dikenal sekarang tetapi berukuran lebih besar. Penggunaannya secara manual, yakni dengan cara mengoleskan tinta pada permukaan kayu yang berukir itu kemudian dicapkan pada selembar kertas. Teknik tersebut dikenal sebagai 'pencetakan blok' yang tepat untuk budaya tulis yang menggunakan ideogram dan bukannya rangkaian alfabet yang terdiri dari beberapa huruf. Oleh karena itu, sarana pencetakan itu lebih tepat disebut 'alat cetak', bukan 'mesin cetak'. Barulah pada abad kelima belas, orang Korea menciptakan suatu bentuk alat cetak yang bisa digerakkan mungkin semimekanis - mirip dengan mesin cetak seperti yang tergambar pada temuan Johann Gutenberg (1400-1468) dalam abad yang sama.

Dalam sejarah Eropa, Johann Gutenberg di kemudian hari tampil sebagai penemu mesin cetak, apalagi setelah ia berhasil mencetak kitab Injil pada tahun 1456. Tetapi bukan tidak mungkin, jika temuan Gutenberg tersebut didorong oleh berita-berita tentang teknik cetak-mencetak yang dimulai dari Dunia Timur. Praktik cetak-mencetak itu kemudian berkembang luas di Eropa. Pada tahun 1500, sekitar 250 usaha percetakan didirikan di berbagai tempat di Eropa, dan diperkirakan menghasilkan kira-kira 27.000 judul buku. Jika sebuah judul buku dicetak rata-rata 500 eksemplar maka pada saat itu telah beredar 13,5 juta eksemplar di Eropa yang berpenduduk sekitar seratus juta jiwa. Tidak salah lagi jika dikatakan bahwa dalam konteks sejarah kebudayaan Eropa, percetakan, sama halnya dengan tulisan, diidentifikasikan sebagai salah satu tonggak sejarah yang membawa kemajuan pemikiran manusia. Seorang pelarian Eropa Timur yang kemudian tinggal di Inggris, Samuel Hartlib (1600-1662), mengatakan bahwa percetakan telah menyebarluaskan ilmu pengetahuan sedemikian rupa sehingga orang biasa, karena mengetahui hak dan kebebasannya, "tidak mau diperintah lagi dengan cara penindasan". ${ }^{6}$

Sementara itu, di Indonesia, mesin cetak mulai didatangkan orang Belanda sejak masa jaya VOC, terutama menjelang perempat pertama abad ketujuh belas. Mesin cetak pertama didatangkan pada tahun 1624 oleh para misionaris Gereja Protestan Reformis Belanda, digunakan untuk mencetak brosur, almanak, buku, dan materi cetak lainnya untuk menunjang kegiatan misionaris di Kepulauan Nusantara. ${ }^{7}$ Mesin-mesin cetak itu telah mendorong timbulnya usaha percetakan sekaligus penerbitan; jadi belum ada diferensiasi

6 Uraian tentang asal-usul percetakan ini dirangkum dari Salzmann (1998, Bab 11, terutama hlm. 245-252); Briggs dan Burke (2006, Bab 2, terutama hlm. 18-26); bandingkan Williams (1973, Bab 2); Gedin (1977, Bab 1). Salzmann menyebutkan bahwa kertas telah ditemukan dalam abad kedua di Asia Tengah, kemungkinan negeri Cina; sedangkan tinta diketahui digunakan di Mesir dalam masa yang lebih tua lagi, yakni abad ketiga sebelum Masehi.

Menurut Boxer (1983: 14-15), dalam kapal-kapal VOC ikut serta personel kerohanian yang kelak bertugas menyebarluaskan ajaran Kristen, selain kelompok pegawai lainnya, yakni pegawai niaga, personel militer dan maritim, dan tukang/perajin. 
antara kedua jenis usaha itu. Johan Nieuhof, yang pernah bermukim di Batavia antara tahun 1667-1670, sempat menyaksikan produk cetakan pertama di kota tersebut berupa buku-buku almanak yang disebut Tytboek (1659). ${ }^{8}$ Selain buku almanak, kamus bahasa Belanda-Melayu mulai diterbitkan (1677), disusul penerbitan kitab Perjanjian Baru (1693) dalam bahasa Portugis yang pada waktu itu merupakan bahasa yang banyak digunakan di Hindia Timur; dan berbagai materi cetakan untuk kepentingan Gereja. Demikianlah, pada pertengahan abad ketujuh belas telah tumbuh usaha penerbitan di Batavia yang dikelola oleh individu ataupun Gereja.

Antara tahun 1659-1695 sekurang-kurangnya terdapat enam unit usaha percetakan/penerbitan di Batavia. ${ }^{9}$ Mereka adalah kelompok 'penerbit kota' (stadsdrukker) ${ }^{10}$ yang boleh dikatakan relatif independen dari kepentingan VOC, dan memang tidak melibatkan unsur organisasi dagang itu. Cukup menarik karena di tengah kekuasaan monopolistiknya, Kompeni (sebutan populer VOC) memberikan kesempatan kepada usaha percetakan di luar kendalinya. Barangkali, usaha percetakan pada waktu itu masih dipandang kecil nilai ekonomisnya, dan tidak digunakan untuk mencetak materi yang dianggap berakibat membahayakan kedudukan pejabat dan organisasi dagang tersebut. Cetak-mencetak tidak lebih sebagai kegiatan teknis, dan belum dilihat sepenuhnya sebagai salah satu unsur yang bisa menyebarkan gejala perubahan kebudayaan.

Tampaknya, VOC belum mempersiapkan unit percetakannya sendiri secara profesional, atau paling tidak belum memiliki tenaga pencetak sendiri. Hal itu terlihat pada penjualan mesin cetak milik Kompeni kepada Hendrik Brants, seorang penjilid buku di Batavia, yang berasal dari keluarga pedagang buku di Amsterdam. Kepada Brants itulah kemudian (pada tahun 1688) Kompeni mengontrakkan pencetakan dokumen VOC selama dua tahun. Namun, karena hanya memiliki keterampilan sebagai penjilid buku, Brants mengajak rekanan lain yang piawai dalam teknik pencetakan sehingga timbul sistem subkontrak dalam cetak-mencetak. Sistem itu ternyata tidak bisa menjamin mutu produknya; bahkan bisnis Brants gulung tikar dua tahun kemudian. Beberapa kali pejabat VOC mengganti rekanan percetakannya, yang bisa diartikan bahwa mereka tidak puas atas hasil pekerjaan para rekanan itu. Memang terasa 'aneh' jika seorang penjilid buku memperoleh pesanan mencetak dokumen penting dalam jumlah yang cukup besar (volume dan nilainya) jika dilihat dari total waktu kontrak yang mencapai tahunan. Diduga, hal-hal seperti itulah yang merupakan wujud nyata penyakit kolusi dan korupsi yang berjangkit dalam tubuh Kompeni.

Pada tahun 1719, VOC membeli dan membangun unit percetakan sendiri yang baru. Gubernur Jenderal Gustaaf Willem Baron van Imhoff yang naik

$8 \quad$ Mungkin dari kosakata Belanda tijd 'waktu' dan boek 'buku'. Johan [Joan] Nieuhof menuliskan kesaksiannya itu dalam Gedenkwaerdige zee- en lantreize door de voornaemste landschappen van West en Oostindiën (1682); namun eksemplar Tytboek tersebut tidak ditemukan lagi (lihat Kimman 1981: 69).

9 Menurut penelitian François Valentijn, dikutip dari Kimman (1981: 70 cb).

10 Istilah ini dari F. Valentijn yang meneliti usaha percetakan/penerbitan di HindiaBelanda abad ketujuh belas (lihat Kimman 1981: 69-70). 
ke tampuk jabatannya pada tahun 1743 (sampai tahun 1750) tampak semakin menyadari akan pentingnya percetakan/penerbitan bagi kelangsungan kekuasaan VOC. Dikenal sebagai gubernur yang 'liberal', Van Imhoff menampakkan diri sebagai sosok "pencerah dan manusia berbudaya,"11 yang mencoba keras menghapus gambaran korup pada awak Kompeni, berusaha menghentikan penyelundupan candu gelap, mendorong penumbuhan gagasan intelektual dan mengembangkan kehidupan budaya di Batavia. Ia pula yang menyelenggarakan pelatihan dan pendidikan kelautan dan seminari bagi penginjil pribumi.

Meskipun image Gubernur Jenderal Van Imhoff digambarkan demikian ideal, tetap saja melekat 'watak asli kompeni' dalam upaya menegakkan sifat monopolistik organisasi dagang yang dipimpinnya. Dalam hal usaha percetakan/ penerbitan, ia meletakkannya secara langsung dalam subordinansi kekuasaannya; artinya, siapa pun yang akan membuka usaha tersebut harus memperoleh izin dan tetap dalam pengawasan organisasi VOC. Jenis produk yang dicetak pun hanya terbatas untuk keperluan administrasi Kompeni atau kepentingan Gereja. Semua materi cetak harus diperiksa terlebih dulu oleh pejabat VOC yang ditunjuk. Hal itu melahirkan tipe ketiga dalam usaha percetakan/penerbitan, yakni 'penerbit istana' (castle's press), ${ }^{12}$ selain penerbit kota dan sistem kontrak yang telah berkembang sebelumnya.

\section{TERBITNYA BATAVIASCHE NOUVELLES}

Karakter Gubernur Jenderal Van Imhoff yang liberal tetapi juga tegas ternyata menarik perhatian salah seorang bawahannya yang segera 'menangkapnya' sebagai suatu watak yang memberi peluang terhadap ide yang lebih terbuka. Jan Erdman Jordens, nama pegawai itu, tidak pernah disebut-sebut dalam sejarah umum VOC. Ia juga dikenal sebagai pedagang kecil tetapi tidak pernah ada penjelasan usaha dagang apa yang dikembangkannya, tetapi merupakan gejala jamak jika aparatus badan dagang ikut pula berdagang. Namun, yang membedakan Jordens dengan kebanyakan pegawai VOC ialah bahwa ia memiliki semacam idealisme kultural yang tidak hanya mengejar materi. Ia berinisiatif menerbitkan suatu media pemberitaan yang dalam bayangannya bisa menjadi alat komunikasi di antara pejabat dan awak VOC ataupun dengan masyarakat Hindia lainnya.

Sebenarnya, Jordens bukanlah orang (Belanda) pertama yang berminat menerbitkan media komunikasi. Sejarawan kolonial, F. de Haan, yang menulis Oud Batavia (1922-1923), menyebutkan bahwa gubernur jenderal keempat VOC, Jan Pieterszoon Coen, pernah memerintahkan kepada anak buahnya untuk membuat lembaran berita internal Kompeni yang disebut Memorie der Nouvelles. Berbentuk sangat sederhana, Memorie ditulis tangan pada kertas folio empat halaman, isinya berita ringkas kegiatan perdagangan baik di Batavia

11 Kimman (1981: 70) menyebut Gubernur Jenderal Van Imhoff sebagai “an enlightened and cultured man".

12 Lihat Kimman (1981: 70) mengutip F. Valentijn yang menyebutkan bahwa setidaknya VOC memiliki dua unit usaha percetakan di Batavia yang pengelolaanya dipercayakan kepada Hendrik Welzing dan Allard Fronnenbroek (1720-1724). 
maupun di berbagai factorijen (pos-pos perdagangan Belanda), kedatangan dan keberangkatan (kembali) kapal-kapal niaga, dan berita serupa lainnya. Semacam kronikel, Memorie diedarkan di kalangan pejabat dan pegawai Kompeni setelah melalui proses pemeriksaan staf di kantor sekretariat. Tidak pernah ditemukan keterangan tentang jumlah tiras dan frekuensi penerbitan tersebut. ${ }^{13}$ Proses 'penerbitan' yang dilakukan dengan menulis secara manual, bisa dipastikan menjadikan media itu sangat terbatas peredarannya.

Jordens membayangkan media yang digagasnya itu lebih lengkap daripada Memorie; semacam koran yang berfungsi sebagai alat komunikasi yang lebih luas peredarannya. Ternyata, ia tidak bertepuk sebelah tangan karena Gubernur Jenderal memberikan peluang kepadanya untuk mewujudkan impiannya. Ringkas cerita, pada pagi hari, 7 Agustus 1744, edisi perdana Bataviasche Nouvelles en Politique Raisonnementen - nama penerbitan itu; biasanya cukup disebut dua penggal nama pertama - beredar di Batavia. Bentuknya sederhana, berukuran sedikit lebih besar daripada folio, empat halaman, dicetak dalam layout dua kolom - seperti newsletter atau buletin dalam ragam penerbitan media sekarang. Berkala terbit mingguan, tetapi Jordens bercita-cita akan menjadikannya harian; jumlah tirasnya tidak diketahui secara pasti. ${ }^{14}$ Isi utamanya mengenai berbagai ketentuan administrasi VOC pada umumnya, berita-berita tentang perdagangan, kedatangan kapal, pengangkatan dan pemberhentian pejabat VOC; juga pemecatan dan kematian pegawai kantor dagang itu. Selain itu, dimuat beraneka ragam berita seperti pesta-pesta, jamuan, obituari, dan doa-doa keselamatan bagi kapal yang akan berlayar jauh menyeberang ke negeri induk. Sebagai koran dagang, Bataviasche Nouvelles memenuhi sebagian besar halamannya dengan iklan dan berita lelang. Dalam beberapa edisi, koran itu juga menerbitkan karangan tentang sejarah awal koloni, dan sejarah gereja secara singkat - semacam feature yang banyak ditulis dalam media sekarang.

"Tidak ada [tulisan] komentar atau diskusi", tulis Von Faber mengenai isi Bataviasche Nouvelles, dan karena itu 'debat politik' sesuai arti dua patah nama terakhir, Politique Raisonnementen, tidak pernah terjadi. Artinya, opini yang kritis - apalagi terhadap penguasa kompeni - tidak akan ditemukan dalam surat kabar itu. Mungkin Jordens juga 'tahu diri' dengan menghindari isu-isu yang tergolong sensitif seperti korupsi di kalangan pejabat VOC pada

13 Sumber keterangan tentang awal penerbitan media pada masa VOC berasal dari G. H. von Faber, A short history of journalism in the Dutch East-Indies (t.t. [1930?]), khususnya Bab "The 'Bataviasche Nouvelles' 1744-1746", yang dimuat kembali secara lengkap (tetap dalam edisi Inggris) dalam Assegaff (1978: 36-42); juga artikel H. Mohammad Said, “Jaman Gelap Jajahan" dalam buku yang sama (hlm. 43-66). Kajian Smith (1986 [1969]) tentang sejarah pembredelan pers di Indonesia (khususnya Bab III, hlm. 49-58) juga banyak memanfaatkan karya Von Faber. Oleh karena buku Von Faber tidak berhasil ditemukan dalam beberapa perpustakaan di Jakarta, uraian dalam studi ini mengacu kepada sumber-sumber sekunder tersebut, ditambah sumber lain yang akan disebutkan kemudian.

14 Menurut Boxer (1988: 89), pada tahun 1622 terdapat kira-kira 200 personel militer di barak Batavia; sementara kajian Boxer yang lain (1983: 148) menyebutkan terdapat 25.000 sampai 30.000 orang Belanda yang bekerja pada factorijen VOC, termasuk di luar Batavia. Sebagian, kalaupun bukan seluruhnya, di antara mereka itulah yang dibidik Jordens sebagai pembaca korannya. 
waktu itu. Lagi pula, pejabat Kompeni telah menempatkan petugas sensor yang mengawasi usaha percetakan/penerbitan secara ketat termasuk terhadap Bataviasche Nouvelles. Bukan hal yang mengherankan karena koran itu pada dasarnya merupakan penerbitan istana (meski tidak pernah dinyatakan secara resmi), sementara Jordens sendiri merupakan 'orang dalam' VOC. Sebenarnya, ia pun pada awalnya hanya "coba-coba" sambil menjajaki apakah korannya itu akan mendapatkan sambutan dari khalayak pembaca. Ternyata, tanggapan pembaca dan pejabat VOC cukup antusias; langkanya media pemberitaan bagi orang-orang Belanda pada waktu itu telah membuat Bataviasche Nouvelles praktis sebagai satu-satunya bacaan terpilih. Antusiasme itu juga terlihat dari perpanjangan izin usaha yang diberikan kepada Jordens hingga tiga tahun kemudian. Kontrak perpanjangan ditandatangani pada tanggal 9 Februari 1745; artinya Bataviasche Nouvelles masih akan terbit sampai tahun 1748.

Namun, lain di koloni, lain pula di negeri induk. Di Amsterdam, De Heeren Zeventien ('Tuan-tuan XVII', yakni tujuh belas anggota dewan direktur VOC) merasa khawatir dengan peredaran Bataviasche Nouvelles yang semakin meluas. Ada kemungkinan para petinggi VOC di Negeri Belanda merasa 'was-was' jika berita-berita tentang kegiatan perdagangan - meskipun bersifat positif - akan membuka informasi yang bersifat 'rahasia' bagi pesaing mereka. Pada tanggal 20 November 1745, para direktur VOC melayangkan sepucuk surat kepada Gubernur Jenderal G. W. Baron van Imhoff yang berisi permintaan agar Gubernur Jenderal melarang pencetakan dan peredaran Bataviasche Nouvelles karena koran itu dipandang "berdampak membahayakan bagi negeri" ${ }^{15}$ Surat dari Amsterdam tersebut cukup mengejutkan bagi Gubernur Jenderal ataupun Jordens khususnya karena ia merasa tidak pernah memberitakan sesuatu yang sifatnya "berbahaya" sebagaimana dituduhkan oleh Tuantuan XVII itu; juga belum terbukti ada keberatan apa pun dari pembaca atas pemberitaan Bataviasche Nouvelles sampai saat itu. Meskipun Gubernur Jenderal Van Imhoff dikenal berwawasan liberal, bagaimanapun, akhirnya, ia harus tunduk kepada perintah atasannya di tingkat pusat. Gubernur Jenderal tidak mempunyai pilihan lain kecuali menutup usaha Jordens yang telah dirintis dengan susah-payah. Jordens pun, apa boleh buat, harus menelan kenyataan pahit: sejak tanggal 20 Juni 1746 Bataviasche Nouvelles tidak lagi menjadi bagian dari sarapan pagi pembacanya. ${ }^{16}$

$15 \quad$ Von Faber mengutip isi pokok surat De Heeren Zeventien kepada Gubernur Jenderal Van Imhoff tersebut sebagai berikut, "Since we have already traced the harmful consequences in this country of the printing and publishing of the newspaper at Batavia [Bataviasche Nouvelles], Your Excellency will immediately on receipt of this forbid the printing and publishing of that newspaper [...]" (lihat Von Faber dalam Assegaff 1978: 42).

${ }_{16}$ Dokumen arsip Bataviasche Nouvelles yang tersisa sangat terbatas. Menurut Von Faber (dalam Assegaff 1978: 37), tinggal No. 39 (28 September 1745) dan No. 42 (19 Oktober 1745) yang tersimpan di kantor Algemeen Rijksarchief (ARA), Den Haag, Negeri Belanda. Tetapi beruntunglah, karena Kees Bliek, seorang penggali kubur pada makam orang Portugis di Batavia, sempat mengirimkan beberapa edisi kepada kerabatnya di Amsterdam, yang kemudian mereproduksinya dalam bentuk buku. Beberapa edisi lainnya (4 Januari sampai 8 Maret 1745), juga dalam bentuk buku reproduksi, tersimpan di Perpustakaan KITLV (Koninklijk Instituut voor Taal-, Land- en Volkenkunde), Leiden, Negeri Belanda. Informasi tersebut membuktikan bahwa Bataviasche Nouvelles memang pernah terbit sebagai koran pertama di Indonesia. 
Setelah pelarangan terhadap Bataviasche Nouvelles, kegiatan pencetakan berbagai produk penerbitan - yang dihasilkan percetakan kota - di Batavia dalam abad kedelapan belas tetap berlangsung, tetapi tidak ditemukan dalam bentuk media berita. Oleh karena jumlah percetakan atau penerbit relatif sedikit, ${ }^{17}$ penguasa VOC merasa tidak perlu mengaturnya dalam bentuk aturan hukum yang ketat; lagi pula percetakan/penerbit kota itu hanya memroduksi barang cetakan yang tergolong "tidak berbahaya" menurut Kompeni. Namun, karena lama-kelamaan percetakan luar itu mampu menyaingi percetakan istana, Gubernur Jenderal - yang waktu itu dijabat Jacob Mossel, menggantikan Van Imhoff yang telah meninggal dunia - mengeluarkan peraturan tentang percetakan/penerbitan pada tahun 1761 untuk menghindari "perselisihan dan pertengkaran" di antara pencetak/penerbit. ${ }^{18}$ Tidak dijelaskan lebih lanjut apa dan bagaimana peraturan Gubernur Jenderal itu, tetapi pengaturan tersebut menegaskan kembali bahwa bagaimanapun kendali atas monopoli usaha tetap menjadi asas penting bagi VOC. Penerbitan yang sekiranya 'bersih' dari isu politik, tidak mengganggu kemapanan kepentingan pejabat, dan tidak menggerus keuntungan ekonomis Kompeni dipersilakan terus berlanjut. Untuk memperluas penyebaran agama Kristen, misalnya, Gubernur Jenderal memerintahkan pencetakan kitab Ta'limuddin Al-Masehi dalam bahasa Melayu beraksara Arab sehingga dapat dibaca kalangan non-Eropa. Mesin cetak berhuruf Arab memang telah didatangkan dari Negeri Belanda sejak tahun 1746 oleh Seminarium Theologicum Batavia - lembaga ini pula yang berperan menyebarluaskan kitab-kitab ajaran Kristiani. Sementara itu, Lodewijk Dominicus, seorang pengusaha percetakan kota sejak tahun 1773, meneruskan usahanya dengan menerbitkan kumpulan puisi, kamus, dan almanak. Dua tahun kemudian, tahun 1775, ia menerbitkan dwimingguan, Het Vendunieuws (Berita Lelang), yang lebih 'kompatibel' dengan kepentingan para pedagang dan pejabat Kompeni.

\section{PENUTUP}

Riwayat singkat Bataviasche Nouvelles dan bermacam usaha percetakan pada masa VOC mencerminkan beberapa hal. Pertama, bagaimanapun VOC telah memperkenalkan alat baru, yaitu mesin cetak, yang kemudian menandai babak baru dalam teknologi penerbitan dan komunikasi di Indonesia. Dilihat dari saat pengoperasian mesin cetak pertama di Batavia pada tahun 1650an, terdapat selisih hanya kurang dari satu abad dari penemuan awalnya di Eropa; bahkan lebih cepat daripada yang beroperasi pertama kali di St. Petersburg, Rusia, pada tahun 1711. Namun, tidak seperti di Eropa yang telah

17 Menurut Kimman (1981: 70 cb), mengutip F. Valentijn, sampai tahun 1719, setidaknya terdapat enam usaha percetakan di Batavia miliki pedagang Belanda dan misionaris yang dioperasikan secara komersial. Jumlah itu tidak termasuk dua unit percetakan milik VOC seperti yang telah disebutkan.

${ }_{18}$ Lihat Kimman (1981: 71) mengutip J. A. van der Chijs, “[ . . .] that in 1761 an instruction was handed down by the Governor General to regulate the competition between both printers [penerbit-kota dan penerbit-istana] in order to avoid 'discord and disputes'". 
menimbulkan semacam 'revolusi' dalam komunikasi, ${ }^{19}$ efek percetakan beserta produknya di Tanah Hindia pada waktu itu masih sangat terbatas. Percetakan lebih dimanfaatkan untuk menopang monopoli VOC terutama untuk melayani keperluan administrasi, menunjang kegiatan misionaris, dan penerbitan bacaan bagi sedikit pejabat dan pegawai kongsi dagang tersebut. Pada sisi lain, masyarakat di Kepulauan Nusantara memiliki tradisi tulis-menulis sendiri yang telah berlangsung jauh hari sebelumnya dalam bentuk tulisan tangan, ragam aksara dan bahasa setempat tanpa 'sentuhan' mesin cetak. ${ }^{20}$ Berbagai serat, kitab, babad, dan sebagainya, masih terus dianggit para empu, pujangga kraton, dan golongan cerdik pandai lainnya, tanpa terpengaruh oleh mesin-mesin cetak yang berdatangan di Batavia. Di Eropa, sementara itu, percetakan telah menimbulkan kesadaran akan pentingnya publisitas di kalangan pengusaha dalam menjalankan kegiatan ekonomi ataupun bagi lingkaran elite politik untuk membangun image kekuasaannya.

Hal kedua, berkaitan erat dengan keberadaan mesin cetak, tidak berlebihan jika dikatakan bahwa penerbitan media cetak di Indonesia pun sesungguhnya memiliki akar yang menjalar dari kurun waktu yang panjang - meskipun penerbitan itu diusahakan oleh orang Belanda. Dengan segala kesederhanaan dan keterbatasannya, Bataviasche Nouvelles lahir sedini yang terjadi di Eropa, dan tidak terlalu salah jika dikatakan sezaman dengan The Spectator, majalah terkenal yang terbit pertama kali di Inggris pada tahun 1714; atau bahkan lebih awal dari Encyclopaedia Britannica edisi pertama yang terbit pada tahun $1771 .{ }^{21}$ Di samping untuk memenuhi keperluan akan publikasi perdagangan, khususnya berkaitan dengan monopoli VOC, penerbitan Bataviasche Nouvelles mungkin didorong oleh semangat orang Belanda sendiri bahwa negerinya merupakan salah satu pelopor penerbitan media komunikasi massa di Eropa pada abad ketujuh belas. Terbitnya La Gazette d'Amsterdam pada tahun 1662, misalnya, menandai kepeloporan itu; sedangkan Les Gazettes de Hollande sengaja diterbitkan dalam bahasa Prancis supaya dapat dibaca masyarakat Prancis yang waktu itu merasakan media di negerinya sendiri masih 'dicengkeram' oleh sistem monarki absolut.

Ketiga, reputasi Bataviasche Nouvelles sebagai koran pertama di Indonesia tidak dengan sendirinya mencerminkan tumbuhnya kebebasan menyatakan pendapat publik sebagaimana prinsip dasar media pemberitaan. Dengan kata lain, koran itu tidak mampu membangun ruang publik yang bisa memediasi berbagai kepentingan pembacanya sekalipun pembacanya itu relatif homogen yakni orang-orang (pedagang) Belanda sendiri. Barangkali, ketidakmampuan membangun ruang publik itu bukanlah 'kesalahan' Bataviasche Nouvelles (Jordens dan kawan-kawan) sepenuhnya tetapi kedudukannya sebagai

19 Lihat Briggs dan Burke (2006, terutama Bab 2). Kedua penulis itu menyebut masa antara tahun 1450-1789 sebagai “dari 'revolusi percetakan' sampai Revolusi Prancis dan Revolusi Industri".

20 Kitab Tjandrakarana, misalnya, yang berisi tembang dan semacam kamus, diperkirakan ditulis pada 700 Saka. Tentang riwayat berbagai kitab dalam bahasa Jawa (kuno, tengahan, modern), lihat dalam R.M. Ngabehi Poerbatjaraka dan Tardjan Hadidjaja, Kepustakaan Djawa (1957); bandingkan Salzman (1988: 253-255) untuk pembahasan etnografi tulisan yang lebih umum.

${ }^{21}$ Lihat data dalam Gedin (1977: 13); Briggs dan Burke (2006: 36-37). 
penerbitan istana telah membuatnya terpaksa harus menunduk kepada VOC yang berperan mutlak sebagai pemegang saham tunggal, patron, pengawas sekaligus konsumen yang menentukan hidup-matinya penerbitan itu. Kompeni telah menjadikan Bataviasche Nouvelles sebagai satu-satunya sumber informasi publik yang terbatas, baik dari segi isi maupun peredarannya dan tidak memberikan peluang bagi penerbitan media pemberitaan alternatif yang lebih netral. Ditambah dengan belum adanya regulasi mengenai penerbitan media (pemberitaan), sangat memungkinkan bagi penguasa VOC untuk dengan gampang menghentikan langkah suatu penerbitan media dengan alasan "membahayakan negara" meskipun tidak pernah jelas apa maksud alasan itu dan barangkali juga "bahaya" yang pernah disangkakan terhadap Bataviasche Nouvelles tidak pernah ada. ${ }^{22}$ Bagaimanapun, Jordens pantas dicatat sebagai 'agen perintis' yang berusaha membuka ruang publik tetapi terantuk oleh sikap monopolistik yang ditunjukkan oleh bangsanya sendiri.

Akhirnya, patut pula diingat bahwa selain upaya Jordens untuk mendorong komunikasi lebih terbuka dan bersikap egaliter, ada upaya serupa - meskipun tak sama - yang dilakukan Dirk van Hogendorp ${ }^{23}$ yang datang ke Tanah Jawa saat-saat menjelang penguburan VOC pada tahun 1799. Ia banyak melontarkan kritik pedas kepada Kompeni, misalnya menuntut supaya rakyat (penduduk tempatan) diberi kebebasan untuk bekerja sesuai pilihannya dengan cara menghapuskan perbudakan. Persentuhannya dengan berbagai bacaan intelektual, ${ }^{24}$ mendorong Van Hogendorp menulis novel Kraspoekol of de slavernij:een tafereel der zeden van Neerlands Indiën (1800, tentang 'Pukulan keras atau perbudakan') yang melukiskan kekejaman seorang majikan terhadap budaknya. Tidak salah lagi, novel itu merupakan kritikan tajam terhadap sistem perbudakan VOC. Ia juga mengecam keras pendidikan di Hindia, khususnya di Batavia di bawah Kompeni, yang dikatakannya "lebih buruk daripada neraka," dan lebih memilih "mematahkan leher orok saya yang baru lahir daripada sengsara membawanya ke Batavia". ${ }^{25}$

Semangat yang membela dan mungkin sarkasme Van Hogendorp yang kemudian sangat dikenal sebagai tokoh liberal pada masa kolonial Belanda - boleh saja berkobar; tetapi layaknya suatu proses, perubahan dari 'rezim dagang' menjadi pemerintahan (negara kolonial) tidak serta-merta terwujud. Hanya terjadi perubahan kecil pada waktu itu karena personel yang

${ }^{22}$ Von Faber menyimpulkan, “What the harmful consequences alluded to actually were they did not say, and probably they never existed [...]" (dalam Assegaff 1978: 42).

23 Dirk van Hogendorp (1761-1822), pernah menjadi kadet dalam tentara Prusia, kemudian bertugas di India dan Hindia. Ia bahkan mengawini seorang wanita Batavia di kemudian hari (lihat Boxer 1983: 143; Boxer 1988: 253).

24 Menurut Boxer (1983: 143), Van Hogendorp sangat terpengaruh buku yang dikarang oleh penulis avant garde Prancis, Abbe Raynal, Histoire philosophique et politique des établissements et du commerce des Européens dans les deux Indes ('Sejarah Filsafat dan Politik tentang Kedudukan dan Perdagangan Orang-orang Eropa di Kedua Hindia' [Timur dan Barat], 1770 ). Melalui buku itu, Van Hogendorp menilai sepak terjang perdagangan dan kolonialisme Eropa.

${ }^{25}$ Boxer (1988: 253) mengutip pernyataan tersebut ketika Van Hogendorp masih bertugas di Patna, India, "A Batavian education is worse than Hell, and I will rather break the neck of my new born infant than suffer it to be brought to Batavia". Ungkapan sarkastis tersebut tentu sekadar ekspresi kejengkelan yang luar biasa bagi seorang yang tidak dapat memahami sepak terjang VOC. 
menduduki jabatan-jabatan penting dalam pemerintahan masih orang-orang lama dari 'sisa-sisa' VOC; mereka juga masih berpola pikir dan mengikuti cara-cara lama. Dengan kata lain, kelompok konservatif yang menentang gagasan liberal sebagaimana dilancarkan Dirk van Hogendorp masih bercokol kuat. Dalam bidang media cetak, Het Vendunieuws yang terbit sejak tahun 1775 masih tetap bertahan tetapi kemudian dibeli oleh pemerintah tanpa pertimbangan yang jelas; kemungkinan untuk memudahkan pengawasan. Landasan berpikir yang diletakkan oleh De Heeren Zeventien untuk mengontrol media secara keras tampaknya tidak seketika sirna, bahkan kemudian menjadi 'inspirasi' bagi pemerintahan kolonial yang menggantikan VOC dalam menangani penerbitan selanjutnya.

\section{DAFTAR PUSTAKA}

Assegaff, Dja'far Husin (red.). 1978. Bunga rampai sejarah media massa. Jakarta: Mecon Press.

Barker, Chris. 2004. Cultural studies; Theory and practice. Cetakan ulang. London: Thousand Oaks; New Delhi: Sage.

Blake, Reed H. dan Edwin O. Haroldsen. 2005. Taksonomi konsep komunikasi. Diterjemahkan oleh Hasan Bahanan. Cetakan kedua. Surabaya: Papyrus.

Boxer, C. R. 1983. Jan Kompeni: sejarah VOC dalam perang dan damai 1602-1799. Diterjemahkan oleh Bakri Siregar. Jakarta: Sinar Harapan.

Boxer, C. R. 1988. The Dutch Seaborne Empire: 1600-1800. Cetakan ulang. London: Penguin Books.

Briggs, Asa dan Peter Burke. 2006. Sejarah sosial media: dari Gutenberg sampai internet. Diterjemahkan oleh A. Rahman Zainuddin. Jakarta: Yayasan Obor Indonesia.

Croteau, David dan William Hoynes. 1997. Media/Society: industries, images, and audiences. London: Thousand Oaks; New Delhi: Pine Forge.

De Haan, Frederik. 1922-23. Oud Batavia: gedenkboek uitgegeven door het Bataviaasch Genootschap van Kunsten en Wetenschappen naar aanleiding van het driehonderd-jarig bestaan der stad in 1919. Batavia: Kolff. 3 jilid.

Gedin, Per. 1975. Literature in the Market Place. Diterjemahkan dari Swedia oleh George Bisset. Amsterdam: Van Gennep.

Grossberg, Lawrence; Cary Nelson, dan Paula A. Treichler. (red.). 1992. Cultural studies. New York/ London: Routledge.

Kimman, Eduard J. J. M. 1981. Indonesian publishing: economic organizations in a Langganan Society. Baarn: Holandia.

Littlejohn, Stephen W. 1996. Theories of human communication. Cetakan kelima. Belmont: Wadsworth.

McQuail, Denis. 1987. Mass communication theory: an introduction. Cetakan kedua. London: Sage.

Nieuhof, Johan [Joan]. 1682. Gedenkwaerdige zee-en lantreize door de voornaemste landschappen van West en Oostindiën. Amsterdam: Voor de Weduwe van Jacob van Meurs. 
Salzmann, Zdenek. 1998. Language, culture, and society. Boulder, Colorado/ Oxford: Westview.

Smith, Edward C. 1986. Pembreidelan Pers di Indonesia. Diterjemahkan oleh Atmakusumah, Alex A. Rakhim, dan Arie Wikdjo Broto. Cetakan kedua. Jakarta: Pustaka Utama Graffiti.

Williams, Raymond. 1973. Communications. Cetakan ulang. Middlesex: Penguin Books. 